\title{
ANALISIS PERILAKU MASYARAKAT DALAM MENERAPKAN PROTOKOL PENCEGAHAN TERKAIT COVID-19 DI KELURAHAN SUDIREJO MEDAN
}

\author{
Muhammad Adji Wibisono*, Achmad Rifai, Arifah Devi Fitriani \\ S2 IImu Kesehatan Masyarakat, Institut Kesehatan Helvetia Medan \\ *Email : muhammadadjiwibisono@gmail.com
}

\begin{abstract}
ABSTRAK
COVID-19 merupakan penyakit yang disebabkan oleh jenis corona virus baru yaitu Sars-CoV-2. Memburuknya wabah virus corona mengharuskan pemerintah mengambil sikap agar setiap individu menerapkan protokol kesehatan. Berdasarkan data UPT Puskesmas Simpang Limun Kota Medan, akumulasi jumlah pasien covid dari Bulan Maret hingga Juli tahun 2020 tercatat sebanyak 21 orang positif Covid-19, 2 orang meninggal dan 19 orang sembuh. Penelitian ini bertujuan menganalisis perilaku masyarakat dalam menerapkan protokol kesehatan terkait covid-19 di kelurahan Sudirejo Kota Medan. Penelitian kualitatif inidilakukan pada bulan Agustus sampai September 2020. Data dikumpulkan dengan melakukan wawancara dan dokumentasi terhadap 8 orang informan. Data dianalisis menggunakan analisis interaktif Miles dan Huberman. Hasil penelitian, menunjukkan bahwa pengetahuan masyarakat dalam menerapkan protokol kesehatan masih tergolong rendah, sikap masyarakat juga masih tergolong negatif, karena menganggap bahwa Covid-19 adalah isu, selain itu masih banyak masyarakat yang belum menerapkan protokol kesehatan. Berdasarkan hasil tersebut maka dapat disimpulkan bahwa penerapan protokol kesehatan erat kaitannya dengan pengetahuan, sikap dan tindakan masyarakat. Oleh sebab itu disarankan kepada satgas Covid-19 untuk menempelkan poster Edukasi pencegahan Covid-19 di setiap wilayah dengan desain yang menarik perhatian agar masyarakat yang tidak menggunakan media sosial dapat membaca dari poster tersebut sehingga masyarakat dapat menambah wawasannya terkait protokol kesehatan terkait covid-19
\end{abstract}

\section{Kata Kunci : Pengetahuan, Sikap, Tindakan, Protokol Kesehatan, Covid-19}

\begin{abstract}
COVID-19 is a disease caused by a new type of corona virus, namely Sars-CoV-2. The worsening of the corona virus outbreak requires the government to take a stance so that each individual applies health protocols. Based on data from the UPT Puskesmas Simpang Limun in Medan City, the accumulated number of covid patients from March to July 2020 recorded 21 positive people for Covid19, 2 people died and 19 people recovered. This study aims to analyze people's behavior in applying health protocols related to Covid-19 in Sudirejo Village, Medan City. This qualitative research was conducted from August to September 2020. Data was collected by conducting interviews and documentation of 8 informants. Data were analyzed using interactive analysis by Miles and Huberman. The results showed that public knowledge in implementing health protocols was still low, people's attitudes were also negative, because they thought that Covid-19 was an issue, besides that there were still many people who had not implemented health protocols. Based on these results, it can be concluded that the application of health protocols is closely related to people's knowledge, attitudes and actions. Therefore it is advisable for the Covid-19 task force to post Covid-19 prevention education posters in each region with a design that attracts attention so that people who do not use social media can read from the poster so that the public can add insight into health protocols related to covid-19.
\end{abstract}

Keywords: Knowledge, Attitudes, Actions, Health Protocols, Covid-19 


\section{PENDAHULUAN}

Pandemi virus Corona2019-2020 adalah pandemi penyakit coronavirus yang sedang berlangsung dari tahun 2019 (COVID-19), yang disebabkan oleh sindrom pernafasan akut. Wabah ini pertama kali diidentifikasi di Wuhan, Hubei, Cina, pada Desember 2019, dan diakui sebagai pandemi oleh Organisasi Kesehatan Dunia (WHO) pada 11 Maret 2020. ${ }^{2} \mathrm{Di}$ Indonesia, dua kasus pertama COVID-19 dinyatakan positif pada awal Maret 2020, dan sejak saat itu jumlahnya makin meningkat, termasuk angka CFR yang cukup tinggi sekitar $8 \%$ di minggu ketiga Maret 2020. Berdasarkan data Kemenkes RI per tanggal 18Juli 2020 kasus positif infeksi virus corona di Indonesia masih menunjukkan pertambahan dari hari ke hari. Saat ini kasus terkonfirmasi sebanyak 84.882 dengan 43.368 pasien yang sembuh dan sebanyak 4.016 pasien yang meninggal. ${ }^{3}$

Berdasarkan data Dinas Komunikasi dan Informatika (Diskominfo) Sumatera Utara diketahui bahwa pasien yang terkonfirmasi di provinsi Sumatera Utara ada sebanyak 2.923 dengan 695 pasien yang dinyatakan sembuh dan 145 orang meninggal dunia. Kasus COVID-19 pertama kali ditemukan di RSUP Haji Adam malik pada tanggal 17 Maret 2020 yaitu seorang pasien PDP yang sebelumnya melakukan perjalanan ke Luar Negeri yaitu Yerusalem dan Italia. Pasien tersebut sebelumnya berstatus PDP corona dengan kode PDP 01 di RSUP Haji Adam Malik Medan dinyatakan positif corona atau Covid-19. Pasien tersebut meninggal pada 17 Maret 2020 malam.

\footnotetext{
Berdasarkan data Dinas kesehatan Kota Medan yang dikutip dari covid19.pemkomedan.go.id diketahui bahwa pada tanggal 18 Juli 2020 jumlah pasien dalam pemantauan ada sebanyak 1.287 orang (32 orang dalam proses pemantauan, 1.255 orang selesai pemantauan), orang tanpa gejala ada sebanyak 3.119 orang (684 orang dalam proses pemantauan, 2.435 orang selesai pemantauan), Pelaku perjalanan ada sebanyak 2.032 orang (34 orang dalam proses pemantauan, 1.998 orang selesai pemantauan), pasien dalam pengawasan ada sebanyak 2.528 orang (2214 orang pulang, 93 orang meninggal, 221 orang sedang di rawat), dan positif covid-19 ada sebanyak 1.744 (521 orang yang sembuh, 89 orang meninggal dan 1.134 yang sedang di rawat). ${ }^{4}$
}

Berdasarkan bukti ilmiah, COVID-19 dapat menular dari manusia ke manusia melalui kontak erat dan droplet, tidak melalui udara. Orang yang paling berisiko tertular penyakit ini adalah orang yang kontak erat dengan pasien COVID-19 termasuk yang merawat pasien COVID-19. Rekomendasi standar untuk mencegah penyebaran infeksiadalah melalui cuci tangan secara teratur, menerapkan etika batuk dan bersin, menghindari kontaksecara langsung dengan ternak dan hewan liarserta menghindari kontak dekat dengan siapa pun yang menunjukkan gejala penyakit pernapasan seperti batuk dan bersin.Selain itu, menerapkan Pencegahan dan Pengendalian Infeksi (PPI) saat berada di fasilitas kesehatan terutama unit gawat darurat. ${ }^{5}$

Memburuknya wabah virus Corona mengharuskan pemerintah mengambil sikap. Oleh sebab itu pemerintah menyarankan agar setiap individu untuk menerapkan protokol kesehatan COVID-19 sesuai panduan yang telah yang telah dicanangkan oleh Kementerian Kesehatan RI tahun 2020 yaitu menjaga kebersihan tangan dalam artian menjaga kebersihan tangan dengan cairan pencuci tangan atau hand sanitizer, apabila permukaan tangan tidak terlihat kotor. Namun, apabila tangan kotor maka bersihkan menggunakan sabun dan air mengalir. Cara mencucinya pun harus sesuai dengan standar yang ada, yakni meliputi bagian dalam, punggung, sela-sela, dan ujung-ujung jari. Kemudian, jangan menyentuh wajah dalam kondisi tangan yang belum bersih, menerapkan etika batuk dan bersin. Ketika batuk atau bersin, tubuh akan mengeluarkan virus dari dalam tubuh. Jika virus itu mengenai dan terpapar ke orang lain, maka orang lain bisa terinfeksi virus, pakai masker khususnya bagi yang memiliki gejala gangguan pernapasan dan social distancing guna menghadapi pandemi COVID-19. Social distancing merupakan salah satu langkah pencegahan dan pengendalian infeksi virus Corona dengan menganjurkan orang sehat untuk membatasi kunjungan ke tempat ramai dan kontak langsung dengan orang lain.

Ketika menerapkan social distancing, seseorang tidak diperkenankan untuk berjabat tangan serta menjaga jarak setidaknya 1 meter saat berinteraksi dengan orang lain, terutama dengan orang yang sedang sakit atau berisiko tinggi menderita COVID-19.Social distancing mencakup tindakan pengendalian infeksi yang 
dimaksudkan untuk memperlambat penyebaran penyakit dengan meminimalkan kontak erat antara individu. ${ }^{6}$ Metode termasuk karantina; pembatasan perjalanan; dan penutupan sekolah, tempat kerja, stadion, teater, atau pusat perbelanjaan. Individu dapat menerapkan metode jarak fisik dengan tinggal di rumah, membatasi perjalanan, menghindari daerah ramai, menggunakan salam tanpa kontak, dan secara fisik menjauhkan diri dari orang lain. Banyak pemerintah sekarang mengamanatkan atau merekomendasikan jarak fisik di daerahdaerah yang terkena dampak wabah.

Pada akhir Maret 2020, WHO dan badan kesehatan lainnya mulai mengganti penggunaan istilah " Social distancing " dengan "physical distancing", untuk mengklarifikasi bahwa tujuannya adalah untuk mengurangi kontak fisik dengan tetap menjaga hubungan sosial, baik secara virtual maupun jarak. Penggunaan istilah " social distancing " telah menyebabkan implikasi bahwa orang harus terlibat dalam isolasi sosial yang lengkap, daripada mendorong mereka untuk tetap berhubungan dengan orang lain melalui cara alternatif. $^{\overrightarrow{ }}$

Selain itu, ada beberapa contoh penerapan social distancing yang umum dilakukan, yaitu:bekerja dari rumah (work from home), belajar di rumah secara online bagi siswa sekolah dan mahasiswa, menunda pertemuan atau acara yang dihadiri orang banyak, seperti konferensi, seminar, dan rapat, atau melakukannya secara online lewat konferensi video atau teleconference, tidak mengunjungi orang yang sedang sakit, melainkan cukup melalui telepon atau video call

Salah satu kelurahandi Kota Medan yang terdaftar sebagai zona merah adalah kelurahan Sudirejo. Kelurahan Sudirejo ini sempat viral akibat aksi seorang anggota DPRD yang menolak pemakaman sesuai SOP PDP Covid$19{ }^{8}$ Sehingga banyak pelayat yang datang ke rumah duka tanpa menghiraukan anjuran pemerintah untuk menerapkan social distancing. Hingga saat ini kelurahan Sudirejo ini termasuk daerah yang kurang menerapkan protokoler kesehatan yang ditetapkan oleh Kementerian Kesehatan RI. Berdasarkan data UPT Puskesmas Simpang Limun Kota Medan, adapun akumulasi jumlah pasien coved di wilayah kerja Puskesmas Simpang Limun dari Bulan Maret hingga Bulan Oktober tahun 2020 tercatat sebanyak 72 pasien terkonfirmasi covid- 19 yang sembuh, 5 orang pasien terkonfirmasi covid- 19 yang meninggal dan sebanyak 3 orang pasien terkonfirmasi covid19 yang masih di rawat. Sedangkan untuk pasien suspek diketahui bahwa sebanyak 100 orang pasien suspek covid- 19 yang sembuh, 4 orang pasien suspek covid- 19 yang meninggal, dan 6 orang pasien suspek covid19 yang masih dirawat.Oleh sebab itu peneliti tertarik untuk melakukan penelitian di lokasi ini.

Berdasarkan survey awal yang dilakukan oleh peneliti terhadap 10 orang masyarakat yang ada di kelurahan tersebut diketahui bahwa ada 3 orang yang mengaku tidak terlalu percaya dengan adanya covid-19 sehingga ketiga orang tersebut merasa tidak perlu menggunakan APD atau menjaga jarak dari orang lain. Kemudian ada 5 orang yang menyatakan bahwa mereka percaya bahwa Covid -19 itu ada, akan tetapi mereka tidak bisa hanya berdiam diri dirumah karena harus mencari nafkah untuk kelangsungan hidupnya dan keluarganya. Kemudian peneliti melakukan wawancara dengan beberapa informan yaitu salah seorang pedagang, seorang tukang parkir dan seorang pengunjung pasar di pasar Sudirejo atau yang lebih dikenal dengan pajak simpang limun dan wawancara itu adalah mengenai kepatuhan masyarakat tentang himbauan pemerintah tentang social distancing terkait covid-19. Hasil wawancara dengan 3 orang tersebut menunjukkan bahwa mereka adalah gambaran masyarakat yang ada di kelurahan tersebut yang memiliki sikap apatis terhadap protokol kesehatan yang telah di anjurkan pemerintah untuk diterapkan oleh masyarakat untuk menghindari penularan covid 19.

Berdasarkan paparan di atas, peneliti melihat bahwa perilaku masyarakat dalam menanggapi himbauan pemerintah tentang penerapan protokoler kesehatan yang di anjurkan pemerintah khususnya tentang social distancing di kelurahan Sudirejo masih kategori buruk. Ada masyarakat yang pengetahuannya baik tentang pentingnya menerapkan social distancing tetapi tidak menerapkannya akibat faktor ekonomi, dan ada juga masyarakat yang terlalu percaya dengan berita yang diperoleh dari sumber yang tidak dapat dipercaya yang menyatakan bahwa covid-19 adalah kebohongan publik sehingga masyarakat tersebut tidak perduli akan kesehatannya.

Perilaku masyarakat ini perlu diteliti, oleh sebab itu peneliti meminjam teori perilaku kesehatan sebagai teori untuk memecahkan 
masalah dalam penelitian ini. Berdasarkan teori tersebut diketahui bahwa perilaku kesehatan seseorang dipengaruhi oleh tiga faktor yakni : faktor predisposisi (umur, pekerjaan, pendidikan, pengetahuan dan sikap), faktor pemungkin (jarak ke fasilitas kesehatan), faktor penguat (dukungan keluarga dan tokoh masyarakat) akan tetapi pada penelitian ini, peneliti hanya fokus kepada 3 perilaku saja yaitu meneliti tentang pengetahuan, sikap dan tindakan masyarakat dalam menerapkan social distancing terkait covid-19. Oleh sebab itu tujuan penelitian ini yaitu menganalisis perilaku masyarakat dalam menerapkan protokol pencegahan terkait COVID -19 di kelurahan Sudirejo Medan.

\section{BAHAN DAN METODE}

Tabel 1: Pengetahuan Masyarakat dalam Menerapkan Protokol Pencegahan Terkait Covid -19 Di Kelurahan Sudirejo Kota Medan

\begin{tabular}{ll} 
Kelurahan Sudirejo Kota Medan \\
\hline Pertanyaan \\
mendengar tentang protokol \\
kesehatan? menurut anda, apa \\
itu protokol kesehatan?
\end{tabular}

2. Apakah menurut anda perlu: menerapkan protokol kesehatan di dalam lingkungan keluarga, mengingat anggota keluarga sering keluar rumah?

3. Di tengah gempuran dunia: digital, ternyata cukup banyak warga yang masih menggunakan media cetak sebagai sumber informasinya untuk menambah pengetahuannya seputaran covid-19. Menurut anda, apakah informasi yang dipaparkan oleh media dapat dipercayai $100 \%$ ?

4. Ditengah-tengah

kesimpangsiuran mengenai Covid 19. Bahkan beberapa responden mengaku bingung dengan banyaknya informasi yang bersifat hoax/tidak valid/tidak akurat, sehingga meresahkan masyarakat. Informasi yang ada juga belum terdistribusi secara merata di tiap-tiap lapisan/kalangan masyarakat. Bagaimana anda
Penelitian ini menggunakan jenis penelitian deskriptif kualitatif. Peran peneliti dalam penelitian kualitatif ini adalah sebagai perencana, pengumpul data, penganalisis, hingga akhirnya sebagai pencetus penelitian. Penelitian ini dilaksanakan pada bulan Agustus sampai dengan Oktober 2020 di Kelurahan Sudirejo Kota Medan, dengan pertimbangan di kelurahan Sudirejo. Informan dalam penelitian ini terdiri dari tiga informan, yaitu Informan kunci (Satgas Covid-19), informan utama (masyarakat), Informan Pendukung (Ustad atau Pendeta). Teknik pengumpulan data dilakukan dengan 3 tahap yaitu observasi, wawancara dan dokumentasi. Data dianalisis dengan menggunakan teknik analisis miles, mathtew dan huberman.

\section{HASIL}

: Hasil wawancara

Hasil wawancara terhadap informan diketahui bahwa, sebagian besar infoman dalam penelitian ini memiliki pengetahuan yang baik tentang protokol pencegahan covid 19, meskipun ada satu informan yang tidak tahu dan yang masih menjawab ragu-ragu seperti informan yang bekerja sebagaimasyarakat I dan masyarakat II.

Berdasarkan hasil penelitian diketahui bahwa tidak semua informan bersedia menerapkan protokol kesehatan, salah satu contohnya yaitu informan yang merupakan petugas parkir. Sedangkan responden lain beberapa diantaranya mengaku menerapkan dengan hanya menggunakan masker akan tetapi kadang-kadang masker tersebut digunakan pada saat yang kurang tepat.

Berdasarkan hasil penelitian diketahui bahwa ada sebagian responden yang tidak membaca koran, atau media cetak lainnya, hal tersebut disebabkan oleh minat yang kurang dan ada juga yang menyatakan bahwa media cetak sudah tidak zaman dan ada juga yang menyatakan bahwa informasi yang diterima dari media tidak boleh diterima $100 \%$ karena media sifatnya selalu mempropaganda dan belum tentu akurat atau hoax dan ada juga yang menyatakan sebagai konsumen dari berita tersebut harus terus berhati-hati terhadap beritaberita yang disajikan oleh media.

Berdasarkan hasil wawancara dengan para informan diketahui bahwa respon mereka beraneka ragam, beberapa diantaranya sulit membedakan berita yang valid atau hoax, sehingga lebih percaya dengan media elektronik yaitu televisi, ada satu orang responden yang menyatakan bahwa mendengar informasi tentang protokol kesehatan dari anggota keluarga, dan responden lainnya menyatkan bahwa berita yang disajikan harus dipilah-pilah dan tidak boleh dipercayai 100 persen. 
memilah-milah informasi yang harus anda dengarkan?

5. Sebagai masyarakat Indonesia: yang dikenal dengan masyarakat yang beragama, tokoh agama berperan penting dalam penyampaian pesanpesan mengenai antisipasi covid 19, salah satunya protokol kesehatan. Menurut anda, apakah informasi yang diberikan tokoh agama dapat menambah pengetahuan anda tentang penerapan protokol kesehatan?
Berdasarkan hasil wawancara dengan para informan diketahui bahwa tokoh agama memberikan informasi tentang protokol kesehatan, namun ada juga beberapa informan yang tidak pernah beribadah di rumah peribadatan sehingga kurang tahu apakah ada informasi tentang penerapan protokol kesehatan yang disampaikan oleh tokoh agama.

Tabel 2 : Sikap Masyarakat dalam Menerapkan Protokol Pencegahan Terkait Covid -19 Di Kelurahan Sudirejo Kota Medan

\begin{tabular}{ll}
\hline Pertanyaan & \\
\hline 1. & Bagaimana sikap anda: \\
& tentang protokol \\
& kesehatan?
\end{tabular}

2. Menurut anda apakah: semua orang wajib menerapkan protokol kesehatan?

\section{Hasil wawancara}

Berdasarkan hasil wawancara dengan para informan diketahui bahwa masih banyak responden yang memiliki sikap negatif atau apatis terhadap penerapan protokol kesehatan, seperti petugas parkir yang hanya menggunakan masker apabila ada orang yang memberikan masker, masyarakat II dan V yang kadang lupa menggunakan masker, ada yang menggunakan masker tapi apabila berinteraksi dengan pembeli maskerpun dibuka, sedangkan ustad, pendeta dan juga satgas covid selalu berupaya menerapkan protokol kesehatan.

Berdasarkan hasil wawancara dengan para informan diketahui bahwa tidak semua setuju bahwa protokol kesehatan itu harus diterapkan, seperti petugas parkir, masyarakat II menyatakan sering lupa, sedangkan responden lainnya mengaku selalu menerapkan protokol kesehatan. dan menyatakan bahwa semua orang wajib menerapkannya.

3. Setelah adanya: Berdasarkan hasil wawancara dengan para informan kebijakan new normal, sedikit banyak berkaitan dengan penerapan masyarakat terhadap protokol kesehatan. Menurut anda, apakah kebijakan new normal ini dapat dapat menghentikan penyebaran Covid-19?

4. Bagaimana pendapat: anda tentang masker yang telah tidak layak pakai, apakah masih digunakan atau tidak?

5. Apakah anda percaya: bahwa dengan diketahui bahwa tidak semua responden percaya bahwa dengan kebijakan new normaldapat mengentikan penyebaran covid-19 karena ketidaktahuan tentang new normal tersebut, sedangkan responden lainnya mengaku bahwa dengan kebijakan new normal ini dapat dapat menghentikan penyebaran Covid-19

Berdasarkan hasil wawancara dengan para informan diketahui bahwa masih ada responden yang tidak paham tentang penggunaan masker yang tepat. menerapkan protokol

Berdasarkan hasil wawancara dengan para informan diketahui bahwa masyarakat tidak percaya bahwa dengan menerapkan protokol kesehatan dapat terhindar 
kesehatan anda dari covid 19.

terhindar dari covid 19?

Tabel 3 : TindakanMasyarakat dalam Menerapkan Protokol Pencegahan Terkait Covid -19 Di Kelurahan Sudirejo Kota Medan

\begin{tabular}{|c|c|c|}
\hline \multicolumn{2}{|r|}{ Pertanyaan } & Kesimpulan \\
\hline 1. & $\begin{array}{l}\text { Bagaimana aktifitas anda: } \\
\text { ditengah-tengah pandemi } \\
\text { covid-19 ini ? }\end{array}$ & $\begin{array}{l}\text { Berdasarkan hasil wawancara dengan para informan } \\
\text { diketahui bahwa informan masih beraktifitas seperti biasa, } \\
\text { ada yang bekerja sebagai petugas parkir, berjualan } \\
\text { dipasar, dan ada juga yang bekerja di rumah sambil } \\
\text { mengajari anak yang belajar daring, ada juga informan } \\
\text { yang membatasi aktifitas diluar rumah. }\end{array}$ \\
\hline 2. & $\begin{array}{l}\text { Apakah anda selalu: } \\
\text { menerapkan protokol } \\
\text { kesehatan selama melakukan } \\
\text { aktifitas di dalam maupun } \\
\text { diluar rumah? }\end{array}$ & $\begin{array}{l}\text { Berdasarkan hasil wawancara dengan para informan } \\
\text { diketahui bahwa ada yang tidak menerapkan protokol } \\
\text { kesehatan karena mengaku tidak paham apa yang } \\
\text { dengan protokol kesehatan, dan sebagain lagi mengaku } \\
\text { tidak menerapkan karena mengganggu aktifitasnya, } \\
\text { sedangkan responden lainnya selalu berupaya } \\
\text { menerapkan protokol kesehatan. }\end{array}$ \\
\hline 3. & $\begin{array}{l}\text { Apa yang anda lakukan : } \\
\text { selama pandemi covid-19? }\end{array}$ & $\begin{array}{l}\text { Berdasarkan hasil wawancara dengan para informan } \\
\text { diketahui bahwa yang dilakukan informan adalah bekerja } \\
\text { dari pagi sampe sore hari }\end{array}$ \\
\hline 4. & $\begin{array}{l}\text { Bagaimana pola makan anda: } \\
\text { selama pandemi ini? apakah } \\
\text { anda mengikuti } \\
\text { pemerintah saran } \\
\text { mengonsumsi buah dan } \\
\text { sayur? }\end{array}$ & $\begin{array}{l}\text { Berdasarkan hasil wawancara dengan para informan } \\
\text { diketahui bahwa tidak mengonsumsi makanan bergizi } \\
\text { karena keterbatasan ekonomi, ada juga yang menerapkan } \\
\text { seadanya. }\end{array}$ \\
\hline 5. & $\begin{array}{l}\text { Bagaimana situasi di : } \\
\text { lingkungan tempat tinggal } \\
\text { anda selama pandemi covid- } \\
19 \text { ini ? }\end{array}$ & $\begin{array}{l}\text { Berdasarkan hasil wawancara dengan para informan } \\
\text { diketahui bahwa para tetangga informan atau bahkan } \\
\text { orang-orang yang lalu lalang banyak yang tidak } \\
\text { menggunakan masker dan juga sering berkerumun }\end{array}$ \\
\hline
\end{tabular}

\section{PEMBAHASAN}

Ragamnya persepsi atau sudut pandang masyarakat dianggap sebagai aktivitas menyuarakan ide atau pengetahuan mereka tentang krisis yang saat ini dihadapi. Dari penyebaran Covid-19, di mana penyebaran virus ini telah mengekspansi lebih dari 190 negara termasuk Indonesia. Melihat kondisi ini, di situasi krisis seperti ini, data dan informasi sangat diperlukan sebagai bahan untuk merancang strategi penanggulangan virus yang sudah menjadi pandemi ini. Selain untuk mengetahui bagaimana tingkah laku juga untuk mengetahui bagaimana pengetahuan masyarakat terkait penyebaran virus corona.

Hasil penelitian menunjukkan bahwa hanya sebagian responden yang tahu tentang kebijakan-kebijakan yang dikeluarkan oleh pemerintah untuk menekan angka penyebaran Covid-19 ini dan informan tersebut juga kurang yakin dengan adanya virus tersebut.
Berdasarkan hasil wawancara dengan informan tersebut, maka peneliti menarik kesimpulan bahwa masih banyak masyarakat awam yang tidak perduli dengan kesehatannya karena pengetahuan mereka yang kurang sehingga banyak diantara mereka tidak terlalu memahami apa itu protokol kesehatan, dan kurang percaya tentang Covid 19. Ketidakpercayaan tersebut membuat banyak masyarakat menjadi apatis dengan wabah yang sedang melanda negeri, ditambah lagi minimnya fasilitas yang dimiliki oleh masyarakat untuk mendapatkan informasi yang berguna untuk kesehatannya. Pengetahuan masyrakat yang rendah menyebabkan masyrakat menjadi tidak perduli dengan semua kebijakan-kebijakan yang dipaparkan pemerintah.

Hasil penelitian ini sejalan dengan teori Health belief modelyaitu pada aspek perceived severityyaitu persepsi atau kepercayaan tentang seberapa serius kondisi dan gejala 
tehadap suatu penyakit yang dimiliki individu dan dampak yang ditimbulkan dalam kehidupan sehari-hari. Keterkaitan antara teori dengan fakta dilapangan membuktikan bahwa masih banyak masyrakat yang tidak perduli pada kesehatannya, padahal covid 19 termasuk salah satu virus yang sangat berbahaya.

Upaya yang telah dilakukan oleh Indonesia dalam merespon situasi pandemi Covid-19, antara lain melalui Konsorsium Riset dan Inovasi Covid-19 Kementerian Riset dan Teknologi, Indonesia telah mengembangkan lebih dari 61 inovasi selama masa pandemi dengan pendekatan triple-helix.Diharapkan negara-negara dapat saling berkomitmen untuk berkolaborasi dengan lebih banyak entitas di seluruh dunia khususnya dalam bidang ilmu pengetahuan, teknologi, dan inovasi untuk dapat meneruskan pertumbuhan ekonomi yang berkelanjutan dan mengatasi masalah di masa yang akan datang.

Sikap yang positif merupakan upaya untuk mencegah penularan covid 19. Sikap kepatuhan dalam melakukan pencegahan covid dengan menerapkan protokol kesehatan dipengaruhi oleh beberapafaktorantaralain persepsi, motivasi dan keyakinan terhadap upaya pengontrolan dan pencegahan penyakit, terhadap lingkungan, pelayanan kesehatan, dan kemampuan mengakses sumber yang ada. ${ }^{9}$

Berdasarkan hasil penelitian dengan informan, diketahui bahwa cukup banyak masyrakat yang memiliki sikap negatif terhadap covid 19 ini, diantaranya adalah informan yang merupakan seorang tukang parkir:Hasil wawancara dengan informan menunjukkan bahwa sikap informan sangat negatif karena hanya akan menggunakan masker apabila ada yang memberikan dan sangat jarang sekali cuci tangan. Keyakinan yang dimiliki oleh Informan yang merupakan seorang tukang parkir ini bertolak belakang dengan perceived benefits adalah keyakinan individu terhadap manfaat dari tindakan yang disarankan untuk mengurangi risikoatau keseriusan dampak.

Berbeda halnya dengan para pemuka agama, sebagai seorang suri tauladan maka sikap yang sebaiknya ditunjukkan oleh seorang Ustad dan pendeta adalah sikap positif. Berdasarkan hasil wawancara dengan Ustad, diketahui bahwa informan memiliki sikap yang positif dengan menyatakan protokol kesehatan merupakan anjuran yang sangat baik untuk diterapkan dan pada tatanan keluarga dan agar selalu berupaya untuk menerapkannaya. Informan menyatakan bahwa semua orang wajib menerapkan protokol kesehatan mengingat bahwa virus corons ini sangat berbahaya, sehingga ita perlau antisipasi dan waspada terhdap virus ini. Informan juga menyatakan bahwa New Normal seperti buah simalakama/ Dilakukan maka akan besar kemungkinanannya jumlah pasien meningkat, tapi apabila tidak dilakukan maka perekonomian yang akan hancur.

Berdasarkan hasil penelitian dengan melakukan wawancara terhadap informan yang merupakan petugas parkir diketahui bahwa aktifitas informan tersebut ditengahtengah pandemi covid-19 ini adalah tetap bekerja dari pagi hingga pasar tutup. Selain itu informan yang merupakan tukang parkir menyatakan bahwa tidak menerapkan protokol kesehatan selama melakukan aktifitas di dalam maupun diluar rumah. Hal ini erat kaitannya dengan kondisi sosial mayoritas masyrakat Indonesia yang menengah kebawah. Dimana masyarakat harus bekerja sehari-harinya untuk mencukupi makannya dan anggota keluarganya yang lain.

Hal ini sejalan dengan teori health belief model yaitu Perceived Barries adalah suatu hambatan yang dirasakan individu untuk melakukan tindakan kesehatan yang disarankan, individu tersebut mempertimbangkan keefektifan tindakan terhdap persepsi bahwa biayayang dikeluarkan mahal, berbahaya, tidak menyenangkan, menyita waktu, atau merepotkan.

Hasil wawancara dengan Informan yaitu masyarakat II diketahui bahwa informan juga masih melakukan aktifitas seperti biasa, sama halnya dengan petugas parkir, Informan yaitu masyarakat II juga tidak menerapakan protokol kesehatan dengan menyatakan bahwa hanya menggunakan masker apabila diingat.

Informan masih melakukan aktifitas seperti biasa yaitu tetap berjualan di pasar, dan hanya akan menggunakan masker apabila sedang sepi pedagang, karena kalau pakai masker suaranya menjadi tidak jelas dan kadangkadang pembeli menjadi pergi karena dianggap mempermainkan. Menurut informan selama pandemi ini, informan tetap beraktifitas 
seperti biasa dan tentang saran pemerintah untuk rajin mengonsumsi buah dan sayur, informan mengaku bahwa makan sayur namuntidak terlalu sering mengonsumsi buah karena harga yang mahal dan menurut informan situasi di lingkungan tempat tinggalnya selama pandemi covid-19 ini saja seperti tidak terjadi apa-apa.

Telemedicine adalah teknologi yang memungkinkan pasien berkonsultasi dengan dokter secara privat, tanpa harus bertatap muka secara langsung. Konsultasi dengan dokter membantu pasien mendapatkan informasi mengenai dugaan diagnosis, perawatan atau penanganan pertama pada penyakit maupun kasus cedera, hingga tipstips untuk meningkatkan kesehatan tubuh. Di beberapa negara dunia, penggunaan teknologi telemdicine sudah dilakukan sejak lama. Namun di Indonesia, teknologi ini baru mulai umum digunakan dalam beberapa tahun terakhir. Dengan berubahnya pola kehidupan pada era digital, banyak sektor mengikuti perkembangan ini, termasuk kesehatan. Bahkan, Organisasi Kesehatan Dunia (WHO), telah memiliki divisi khusus yang berkaitan dengan bidang kesehatan digital. Telemedicine merupakan salah satu hasil utama dari perkembangan sektor kesehatan di bidang digital. Menurut WHO, ada empat hal yang mendasari keberadaan telemedicine, yaitu: Bertujuan sebagai pendukung perawatan secara klinis Menjadi solusi atas masalah jarak dan geografis dalam layanan kesehatan Inovasi menggunakan teknologi informasi terbaru Meningkatkan kualitas hidup dan kesehatan masyarakat luas. Di Indonesia, penggunaan telemedicine dianggap bisa mengatasi sejumlah tantangan yang selama ini menghambat pemerataan akses kesehatan, seperti persebaran tenaga kesehatan yang belum merata, masalah geografis, dan kurangnya fasilitas kesehatan di beberapa wilayah tertentu.

\section{KESIMPULAN}

Kesimpulan dalam penelitian ini yaitu sebagai berikut:

1. Pengetahuan masyarakat dalam menerapkan protokol pencegahan terkait covid -19 di kelurahan Sudirejo Kota Medan masih tergolong rendah, hal ini sesuai dengan teori Health belief model yaitu pada aspek perceived severity.
2. Sikap masyarakat dalam menerapkan protokol pencegahan terkait covid -19 di kelurahan Sudirejo Kota Medan masih banyak yang negatif, hal ini bertolak belakang dengan teori perceived benefits.

3. Tindakan masyarakat dalam menerapkan protokol pencegahan terkait covid -19 di kelurahan Sudirejo Kota Medan, masih banyak ditemukan masyarakat yang bekerja dan tidak menerapkan protokol kesehatan. Hal ini sesuai dengan teori health belief model yaitu Perceived Barries.

\section{UCAPAN TERIMA KASIH}

Peneliti mengucapkan terima kasih kepada Lurah Kelurahan Sudirejo Kota Medan yang telah memberikan ijin penelitian untuk dapat melaksanakan penelitian dan juga kepada seluruh jajarannya dan masyrakat yang ada di kelurahan Sudirejo Kota Medan

\section{DAFTAR PUSTAKA}

1. https://www.google.com/search?client $=$ firefox- $\mathrm{b}$ -

$d \& q=1 . \% 09$ Memberi+nama+penyakit+ coronavirus+\%28COVID-

$19 \% 29+$ dan+virus+yang+menyebabka nnya\%22+.Organisasi+KesehatanDun ia+\%28WHO\%29.Diarsipkan+dari+ya ng+asli+pada+28+Februari+2020+.Dia kses+pada+23+Juni+2020+

2. timeline-wabah-virus-coronaterdeteksi-pada-desember-2019hingga-jadi: Diakses pada 23 Juni 2020

3. covid19.pemkomedan.go.id

4. Parker-Pope, Tara (19 Maret 2020)."Memutuskan Berapa Jarak yang Harus Anda Pertahankan" .The New York Times .ISSN0362-4331 .Diarsipkan dari aslinya pada 20 Maret 2020 .Diakses pada 20 Maret 2020

5. https://id.wikipedia.org/wiki/Pandemi k oronavirus di Indonesia-socialdistancing

6. https://health.detik.com/beritadetikhealth/d-4960542/anggota-dprdmedan-ingin-telan-corona-adakahefeknya-bagi-pencernaan

7. Zaharah, Zaharah; Kirilova, Galia Ildusovna. Impact of Corona Virus 
Outbreak Towards Teaching and Learning Activities in Indonesia. SALAM: Jurnal Sosial dan Budaya Syar-i, 2020, 7.3.

8. Darmalaksana, Wahyudin. Corona Hadis. Fakultas Ushuluddin UIN Sunan Gunung Djati Bandung, 2020.
9. Purnamasari, S.R. Penerapan Model Learning Cycle 7e (Elicit, Engange, Explore, Explain, Elaborate, Evaluate, And Extend) Untuk Meningkatkan Kemampuan Koneksi Matematis Dan Self-Efficacy Siswa Sma. SkripsipadaFKIP UNPAS; 2017 